Parallell to that, we observed a marked improvement of the feed efficiency that can be attributed to the good energy value of the sugar beet pulp for rabbits.

The authors prefer to restrict the incorporation level of pulp to $15 \mathrm{p}$. Ioo, as long as the conditions of use, and particularly the rabbit needs for different kinds of fibre (hemicellulose, true cellulose and lignin) are not determined.

\title{
Comparing lucerne meal, safflower meal, beet pulp and grape pomace as roughage sources
}

\author{
D. J. HARRIS, N. P. JOHNSTON \\ Brigham Young University \\ Provo, Utah 84602 \\ (United States of America)
}

New Zealand White rabbits were fed diets based on lucerne, safflower meal, grape pomace and beet pulp. Though not significant, feeding safflower meal and lucerne produced a higher level of lactation as measured by three week fryer weights than did feeding grape pomace or beet pulp. In addition, safflower meal and lucerne feeding resulted in significantly greater $(\mathrm{P}<0.5)$ eight week fryer weights. Young rabbits, when given simultaneous choice of the four diets, consumed significantly $(\mathrm{P}<\mathrm{O} . \mathrm{I})$ more of the safflower ration. Preference for lucerne was significantly $(\mathrm{P}<0 . \mathrm{I})$ greater than for grape pomace or beet pulp. Rabbits weaned at five weeks were similar in weight by eight weeks to those weaned at eight weeks.

\section{Effect of sodium hydroxide treatment of orange pulp digestibility}

\author{
J. FERNANDEZ CARMONA, J. I. MARTINEZ PASCUAL, J. HERNANDEZ \\ Universidad Politecnica, Valencia (Spain)
}

Digestibility coefficients of seven diets containing $0.3^{\circ}, 60$ and Ioo p. 100 citrus pulp treated or not with calcium hydroxide were determined in New Zealand adult male rabbits. The results showed high standard errors, and there were significant differences between control diet (o p. Ioo) and pure pulp (IOO p. 100). Citrus pulp had a highly digestible fibre fraction but the quality of its protein was poor. The calcium hydroxide treatment did not affect the digestibility figures.

Diets containing $60 \mathrm{p}$. Ioo orange pulp were little palatable and treated pulp was more palatable than the untreated one.

\section{Lucerne utilization by rabbits}

\author{
P. R. CHEEKE, N. M. PATTON \\ Rabbit Research Center, Orogon State University \\ Corvallis, OR 9733 (U.S.A.)
}

Four experiments were conducted with weanling New Zealand White rabbits. In experiment $\mathrm{I}$, treatments were: $\mathrm{O}, \mathrm{IO}, 2 \mathrm{O}, 30$ and $40 \mathrm{p}$. I00 lucerne in a yellow maize soybean meal diet. Average daily gains were lower $(\mathrm{P}<0.5)$ for the $o \mathrm{p}$. Ioo lucerne diet than for the others. In experiment 2, extraction of lucerne with ethanol did not remove its growth-promoting effect, 